\title{
Chemical Composition of Some Greenfeeds Available in Burma for Chicken
}

\author{
Jinzo Obara*, Khin Maung Nyunt**, and Sein Tun** \\ * Faculty of Agriculture, Yamaguchi University, Yamaguchi-shi, 753 \\ ** Institute of Animal Husbandry and Veterinary Science, Rangoon, Burma
}

(Received October 26, 1973)

Freshly harvested, succulent greenfeeds are a rich source of provitamin A, in particular, for chicks to protect them from eye and respiratory infections caused by the deficiency of vitamin A. In Burma there exist several kinds of green grasses being used effectively by poultry farmers, but there have been no available data of chemical composition of these grasses in a fresh basis. In the present study, six kinds of grasses, i. e., Elephant grass or Npier grass (Pennisetum), Kazun (Ipomoea reptans), Kanabaw (Alternanthera nodiflora), Water hyachinth or Beda (Eichonia crassipes), Padawni (Panicum farelatum), and Monsoon grass were subjected to determination of moisture, protein, fiber, ash and carotene for the practical use of poultry industry.

\section{Materials ond Methods}

Grasses were sampled monthly from January to December, 1967, though both Padawni and Monsoon grass were not available during the dry season because of their complete dry-up. Samples were collected mainly from the garden of the people's poultry farm at Sawbwagyigong near Insein and also several places around the campus including the poultry unit of the Department of Veterinary Service, some Kazun being purchased from the bazaar.

When grasses were wet during monsoon season, water was removed from the grass with cloth and/or blown off with moderate wind of electric fan. Immediately after removing the wet they were chopped and mixed and an appropriate amount was weighed for the determination of moisture and carotene. The residual part was air-dried in the sun or in the airconditioned room for several days during the monsoon season. Air-dried grasses were ground in a mill to pass sieve with circular openning $1 \mathrm{~mm}$ diameter and mixed thoroughly. Moisture content was again determined with the ground sample for a calculation of percent content of constituents as a fresh basis. Methods applied for the determination of each constituent were mostly according to Official Methods of Analysis, Association of Official Agricultural Chemists, ${ }^{1}$ and that for carotene was to Nutrition Department Manual of India. ${ }^{21}$

\section{Results}

Average values of 12 -month determinations are shown in Table 1 . Of them, values of both Padawni and Monsoon grass are averages of 8 and 6 determinations respectively, since during the dry season, i.e., in Padawni from February to May and in Monsoon grass from

The study was supported, in part, by the FAO, United Nations.

Jap. J. Zootech. Sci., 45, (4): 216-217. 216

1974. 4 . 
Chemical Composition of Greenfeeds in Burma

Table 1. Mean Values of Monthly Determinations (Per cent in fresh basis)

\begin{tabular}{l|rrrrrr}
\hline & $\begin{array}{c}\text { Elephant } \\
\text { grass }\end{array}$ & Kanabow & Kazun & $\begin{array}{c}\text { Water } \\
\text { hyacinth }\end{array}$ & Padawni $\begin{array}{c}\text { Monsoon } \\
\text { grass }\end{array}$ \\
\hline Moisture & 81.70 & 85.69 & 86.32 & 88.34 & 78.45 & 76.54 \\
Protein & 3.19 & 3.55 & 3.46 & 1.89 & 2.41 & 2.11 \\
Fiber & 5.88 & 2.69 & 2.38 & 2.68 & 7.91 & 7.66 \\
Ash & 2.80 & 2.52 & 2.02 & 2.12 & 2.27 & 2.12 \\
Carotene* & 11.61 & 10.43 & 8.51 & 6.68 & 9.34 & 12.57 \\
\hline
\end{tabular}

* Expressed in $\mathrm{mg}$ per $100 \mathrm{~g}$ of fresh grasses.

February to July, they are dry up completely. Contents are expressed in percentage of fresh basis and the carotene is in $\mathrm{mg}$ per $100 \mathrm{~g}$ of fresh grasses.

There are several kinds of Kazun and some are used by man as a vegetable in Burma. Three Kazuns of them, that is, Burmese Kazun (Ipomoea aquatica), Chinese Kazun (Ipomoea reptans) and field Kazun were determined to be compared in January. There was no big difference in amounts of constituents among these Kazuns except higher protein content in Chinese Kazun, $3.64 \%$ in quantity, while that of others was less than $3.0 \%$.

\section{Discussion}

Chemical analysis of greenfeeds on fresh basis is necessary for poultry farmers to use them as a source of vitamin A. Six kinds of grasses in common were subjected to analysis every month during the year irrespective of the growing stages. Moisture content was such that Water hyacinth was juiciest and came Kazun, Kanabaw, Elephant grass, Padawni, and Monsoon grass in the decreasing order. It is reasonable because the Water hyacinth is a water weed and Kazun is also planted on a watery soil. The carotene content was found to be the highest in Monsoon grass and then came Elephant grass, Kanabaw, Padawni, Kazun, and Water hyacinth in the decreasing order. Water hyacinth contained carotene at about a half that of Monsoon grass as well as Elephant grass. Protein was the highest in Kanabaw and Kazun, and followed by Elephant grass, Padawni, Monsoon grass and water hyacinth. Fiber was over twice higher in Padawni, Monsoon grass and Elephant grass as compared with other three grasses. There were no big differences in ash content.

Although both Padawni and Monsoon grass are nutritious and a good source of carotene during the monsoon season despite of relatively high content of fiber, these grasses are short and thin but bear flowers and seeds and dry up soon after the monsoon season is over. Kazun, Kanabaw and Elephnt grass, on the other hand, seemed most favorable greenfeeds for the chicken throughout the year.

It is customarily advised in Burma that daily amounts of greenfeeds to be fed to the chicken are roughly 1 viss $(1.6 \mathrm{~kg}$ ) for 0 to 2 -month of age, 2 visses for 3 -month to maturity and 3 visses for layers per 100 birds, respectively. The present study would contribute to justify that the requirement of vitamin $A$ of the bird would be possibly fulfilled by this amount.

\section{References}

1) Official Methods of Analysis, Association of Official Agricultural Chemists, Washington, U. S. A., 1955.

2) Nutrition Department Manual, All India Institute of Hygiene and Public Health(Indistinct the published year). 